Article

\title{
System Dynamics Modeling for Supporting Drought-Oriented Management of the Jucar River System, Spain
}

\author{
Adria Rubio-Martin *(D), Manuel Pulido-Velazquez *(D), Hector Macian-Sorribes and \\ Alberto Garcia-Prats $(D)$ \\ Research Institute of Water and Environmental Engineering (IIAMA), Universitat Politècnica de València, \\ 46022 Valencia, Spain; hecmasor@upv.es (H.M.-S.); agprats@upv.es (A.G.-P.) \\ * Correspondence: adrumar@upv.es (A.R.-M.); mapuve@hma.upv.es (M.P.-V.)
}

Received: 25 March 2020; Accepted: 10 May 2020; Published: 15 May 2020

\begin{abstract}
The management of water in systems where the balance between resources and demands is already precarious can pose a challenge and it can be easily disrupted by drought episodes. Anticipated drought management has proved to be one of the main strategies to reduce their impact. Drought economic, environmental, and social impacts affect different sectors that are often interconnected. There is a need for water management models able to acknowledge the complex interactions between multiple sectors, activities, and variables to study the response of water resource systems to drought management strategies. System dynamics (SD) is a modeling methodology that facilitates the analysis of interactions and feedbacks within and between sectors. Although SD has been applied for water resource management, there is a lack of SD models able to regulate complex water resource systems on a monthly time scale and considering multiple reservoir operating rules, demands, and policies. In this paper, we present an SD model for the strategic planning of drought management in the Jucar River system, incorporating dynamic reservoir operating rules, policies, and drought management strategies triggered by a system state index. The DSS combines features from early warning and information systems, allowing for the simulation of drought strategies, evaluating their economic impact, and exploring new management options in the same environment. The results for the historical period show that drought early management can be beneficial for the performance of the system, monitoring the current state of the system, and activating drought management measures results in a substantial reduction of the economic impact of droughts.
\end{abstract}

Keywords: water management; resources; system dynamics; drought management; drought impacts

\section{Introduction}

Drought is a natural hazard and, as such, has to be understood as a natural feature of climate. Whether or not a drought becomes a disaster depends on its social, economic, and environmental impacts [1]. Therefore, the key to understanding drought is to acknowledge its different dimensions. Drought affects both surface and groundwater resources and can lead to reduced water supply for in-home consumption and agricultural and industrial activities. Furthermore, it can deteriorate water quality by rising nitrate, ammonium, and phosphate concentrations, and disturb riparian habitats [2,3]. Agriculture is the most affected sector by droughts, but many other sectors may suffer relevant losses, including energy production, tourism and recreation, transportation, urban water supply, and the environment. Sustained drought can cause social, economic, and energy crises, even leading to migration from affected zones (often rural and agricultural-focused) to other regions or nearby countries [4]. Drought is not the only issue that water resource systems have to face regarding water 
availability. Water scarcity refers to continued unsustainable use of water resources and it can be influenced by water management [5]. Increasing water demand due to population growth and the development of the agricultural, energy, and industrial sectors has increased the frequency of water scarcity events that occur when there is a lack of freshwater to meet the demands [6]. Climate change is expected to further aggravate water scarcity because of the increase in drought frequency, severity, and duration $[7,8]$.

There is an increasing concern worldwide about the ineffectiveness of most common drought management practices, largely based on crisis management and on treating symptoms (impacts) rather than the underlying causes associated with them [7]. The European Union has promoted the move from crisis management to drought risk management since 2007 [9]. However, there are gaps in the current water scarcity and droughts policy of the EU, including [10]: conceptual gaps on the understanding of causal relationships between drivers, pressures, status, and impacts; limited data on current and future water demand and availability; policy, governance and implementation gaps regarding measures to increase water supply and to target pressures and impacts caused by droughts.

Drought management plans are tools that aim to reduce the impact of droughts in water resource systems providing a framework for proactive, risk-based management [9]. A coordinated drought plan includes monitoring, early warning and information systems, impact assessment procedures, risk management measures, preparedness plans, and emergency response programs. Without these plans, nations will continue responding drought in a reactive, crisis management mode [7]. A key feature of drought management plans is the use of indices to establish a link between the state of the river basin and the measures to be taken [11]. Drought indices have been developed for assessing drought parameters including intensity, duration, severity, and spatial extent, and are effective tools in the monitoring and management of droughts [2,12]. However, traditional drought indexes often fail at detecting critical events in highly regulated systems, where natural water availability is conditioned by the operation of water infrastructures such as dams, diversions, and pumping wells. Here, ad hoc index formulations are usually adopted based on empirical combinations of several significant hydro-meteorological variables through customized formulations [13]. A system of drought indicators based on levels or thresholds depending upon the degree of water scarcity, and several management actions aiming to mitigate critical situations have been developed in the Jucar River system [11,14]. The creation and institutionalization of multi-sector partnerships have reinforced the development of efficient drought management [15]. To support drought management, scientific approaches including drought characterization, development of risk indicators, and the analysis of economic instruments for risk mitigation are involved in conjunction with the identification, selection, and prioritization of measures to lessen the effects of drought [16]. Decision support systems (DSS) have been developed to study effective drought management strategies, as they are considered one of the most effective tools for integrated water resource management [6]. The use of DSS tools for drought risk management has been increasing during the last decades [17-20]. Studying resource allocation requires the development of DSS able to apply drought management strategies and to dynamically evaluate the status of water resource systems [12]. Multi-criteria decision analysis tools (MCDA) are also oriented to assist the decision-making process in the operation of water resource systems. Nevertheless, a major problem in developing MCDA processes is to understand the risk associated with persistent drought conditions, as risk management involves subjective considerations [6]. The water sector's importance for other sectors requires policies and management strategies that are aware of the potential widespread impacts [21]. Very often, undesired effects can be derived from the execution of drought management strategies. For example, increased groundwater extraction to compensate for the reduction of surface water availability can lower base flows of rivers and streams, and reduce the piezometric level of aquifers [22]. These unexpected consequences can affect river biota, agriculture income, and urban supply in ways that are more damaging or long-lasting in time than the aforementioned drought. Consequently, there is a need for management models able to simulate the complex interactions between different sectors and activities to study the response of water resource systems to drought management strategies. 
System dynamics is a theory of system structure and a set of tools for representing complex systems and analyzing their dynamic behavior [23]. This methodology is particularly useful for studying complex water resource systems with interacting elements and policies, whose behavior cannot be easily predicted [24]. The development of system dynamics models to analyze and improve water resource management has a tradition that dates back to the late 1960s. Since then, and thanks to the development of computer technology and user-friendly system dynamics software, all types of qualitative models have been developed for improving system understanding in water resource systems. However, system dynamics have not been yet applied to highly regulated and complex water resource systems for testing drought management strategies with a quantitative approach and integrating a drought early warning system.

The objective of this paper is to develop a decision support system (DSS) based on system dynamics for the efficient drought management of the Jucar River system. The DSS simulates the management of the Jucar multi-reservoir system integrating monthly-defined reservoir operating rules, stream-aquifer interaction and conjunctive use of surface and groundwater, drought management measures (linked to a system state index), and all this taking into account current water demands and allocation criteria. The tool allows studying the effect of policy and management measures in the system, and it serves as a steppingstone towards the understanding of water resource systems as a holistic system. The DSS provides quantitative results comparable to the historical records for the calibration and validation period. The calibrated model facilitates the design, testing, and selection of new drought management strategies. Section 2 introduces the system dynamics modeling method, details some applications of the methodology for the management of water resource systems and describes the Jucar River system case study. Section 2 also introduces and describes the main features of the system dynamics model developed for the case of study. Section 3 shows and discusses the results, first validating the behavior of the model and later discussing the hydrological and economic results for the simulated scenarios. Finally, Section 4 exposes the conclusions.

\section{Materials and Methods}

\subsection{System Dynamics for Water Resource Systems Modeling}

System dynamics modeling is a methodology of model development that facilities a holistic understanding of water resource systems, as it allows analyzing how different elements of a system relate to one another and permits studying the changing relations within the system when different decisions are included $[25,26]$. The usual purpose of the analysis of system dynamics is to understand how and why the dynamics of concern are generated and to look for managerial policies that can improve the system performance [27]. In system dynamics, the system structure is determined by the positive and negative relationships between variables, feedback loops, system archetypes, and delays $[28,29]$. The totality of the relationships between the system components constitutes the system structure, and the system's structure defines its behavior [30]. This methodology focuses on understanding how the physical processes, information flows, and managerial policies interact to create the dynamics of the different variables of interest [31]. To achieve this knowledge, qualitative/conceptual and qualitative/numerical modeling methods are applied.

Qualitative modeling (e.g., causal loops diagrams and definition of the positive and negative relationships between variables) improves our conceptual system understanding [29]. This type of modeling is often seen as a propaedeutic step to quantitative modeling, where the behavior of the system and the effects of different intervention policies can be visualized through simulation. Qualitative models can be further developed into quantitative models (Figure 1). This change requires a deep knowledge of the existing physical, analytical, and statistical relationships between the variables of the system. In system dynamics, the relationships between variables can be expressed by linear, non-linear mathematical equations and logical expressions such as IF-THEN statements, to introduce 
management policies and rules. To assess the truthfulness of the quantitative models they are validated by comparing their results to the available historical records.

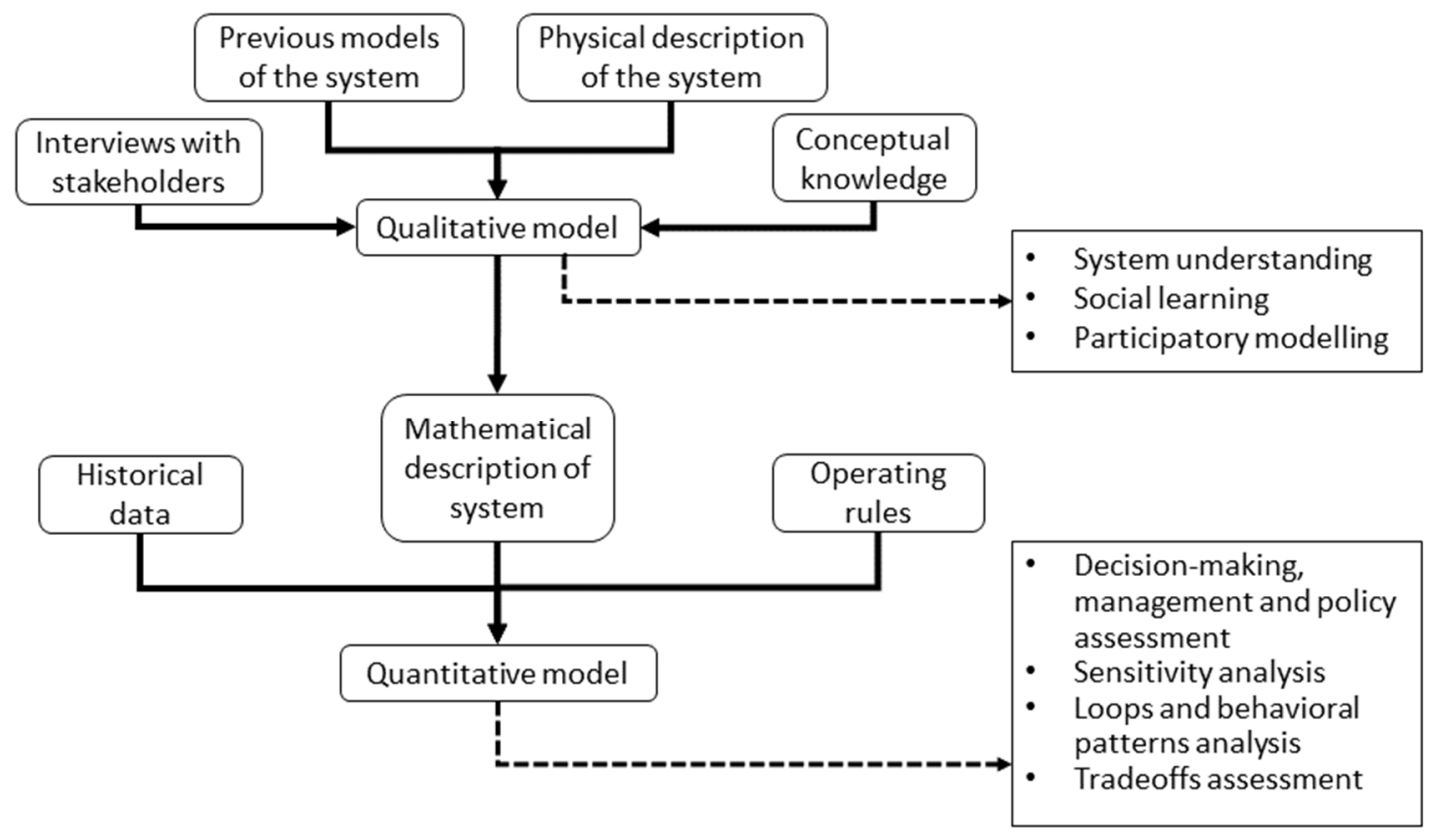

Figure 1. System dynamics modeling framework.

Traditionally, water resources management models were designed with a one-dimensional optimal engineering approach, performed with little regard for social, environmental, or cultural aspects [32]. However, the increased recognition of complexity and uncertainty has promoted the use of more flexible simulation-based tools such as the ones provided by system dynamics [28]. System dynamics provides tools for the graphical representation of systems, facilitates flexible and transparent modeling, eases the holistic understanding of the problem, captures long-run behavioral patterns and trends, facilitates clear communication of model structure and results, promotes sharing modeling, facilitates sensitivity analysis, and it is suitable for policy assessment and selection [25]. System dynamics modeling environments include Powersim (Powersim Corp., 1993), Simile (Simulistics, 2002), Stella (High Performance Systems, 1992), and Vensim (Ventana Systems, 1996). Nowadays, these environments are able to assist modelers and can handle many variables, delays, and interdependent subsystems, allowing the creation of modular object-oriented models, therefore increasing interchangeability and reusability.

The application of system dynamics in water resource management has grown since the 90s. Nowadays, we find applications of system dynamics modeling to study a large variety of water resource issues [29]. They range from region-scale models with multiple demands and frequent water scarcity events [33,34], to models coupling surface and groundwater dynamics for a basin [35], flood management or predicting models [36,37], reservoir operation and water supply for multiple water users [38], and the design of water pricing policies [39]. However, system dynamics application to simulate the management of highly regulated water resource systems integrating multiple reservoirs, operating rules, dynamic drought management, groundwater use, and conflicting water demands remains very limited. Yet all these features are required to analyze the issue of drought early warning and management in complex water resource systems.

Drought management is a multidimensional concept that includes meteorological, ecological, hydrological, environmental, and socioeconomic perspectives. The development of DSS for improving drought management requires the combination of several models [6]. Coupling and analyzing the interactions between these models is often a difficult issue. System dynamics is a methodology that 
provides a common playground for the interaction of different subsystems and submodels, facilitating the analysis of the existing relationships and providing a holistic view of the issue.

\subsection{Case Study: Drought Management in the Jucar River System}

The Jucar River system is located in Easter Spain. The system is subjected to a tight equilibrium between total water demand (1505 $\mathrm{Mm}^{3} /$ year, 2009-2015 period average) and water resource availability (1548 $\mathrm{Mm}^{3} /$ year) [40]. Agriculture is the largest water use by far (89\%), followed by urban (9\%) and industrial uses (2\%). The Jucar is the main source of urban water supply to the city of Valencia and its metropolitan area (about 1,500,000 inhabitants, third largest municipality in Spain). Water from the Jucar is diverted to the Turia River through a $60 \mathrm{~km}$ canal (Canal Jucar-Turia), also used for irrigation of mainly citrus and vegetables (Figure 2). Furthermore, there is an intense water use for irrigation in the lower Jucar, downstream of Tous reservoir, with traditional irrigation districts holding senior water rights dating back to the Middle Ages. Non-consumptive water demands include minimum ecological instream flows and hydropower generation.

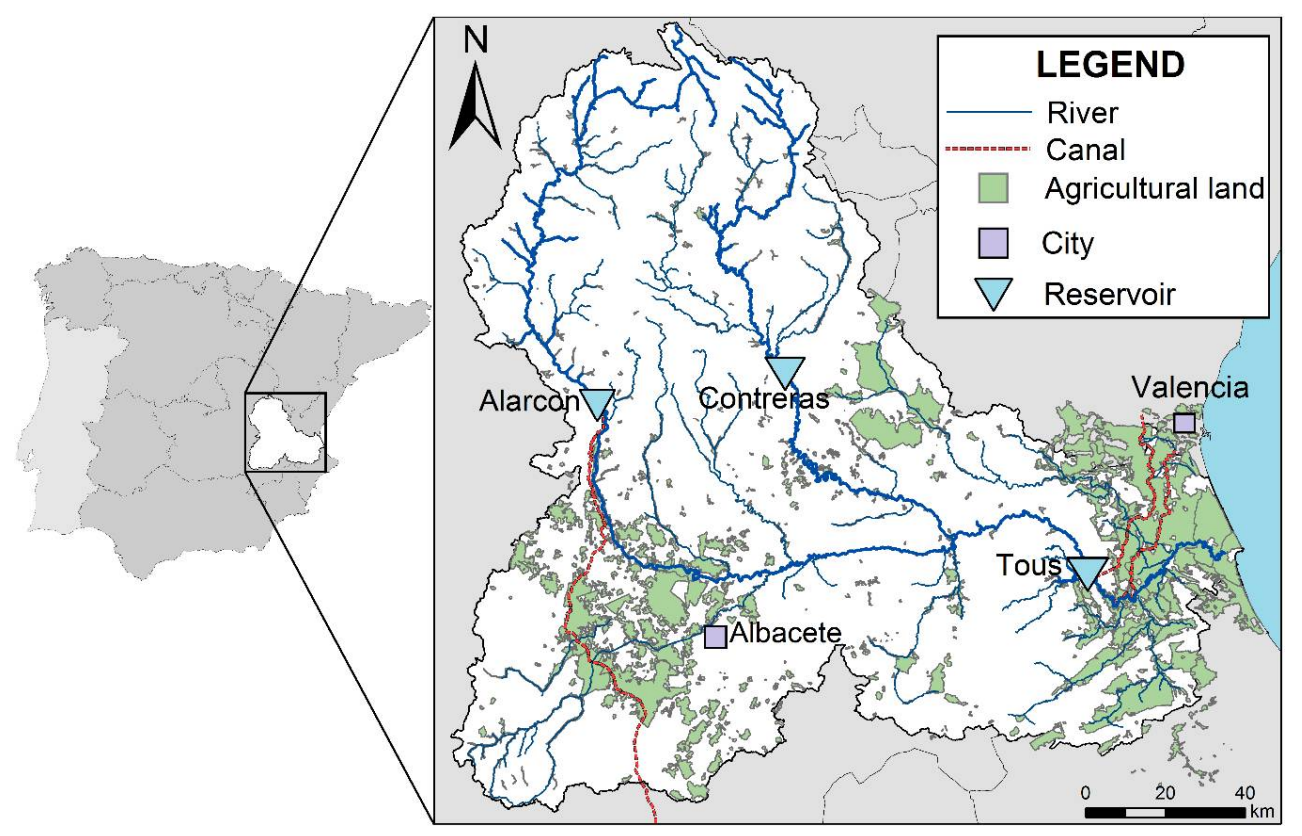

Figure 2. Main features of the Jucar River system included in the model.

The main surface reservoirs are Alarcon (1112 $\mathrm{Mm}^{3}$ of capacity), Contreras (463 $\mathrm{Mm}^{3}$ of useful capacity), and Tous $\left(378 \mathrm{Mm}^{3}\right)$. The regulation capacity of these reservoirs is mainly multi-annual: Alarcon and Contreras are devoted to consumptive uses, while Tous is mostly used for flood protection. The intense overexploitation of the main groundwater body, the Mancha Oriental aquifer (middle basin, near Albacete), for irrigation since the 1970s has shifted the stream-aquifer interaction between Alarcon and Tous from gaining to losing river, diminishing downstream surface water availability. The sustainable use of this aquifer is one of the challenges in the management of the system [41,42]. During droughts, the Plana de Valencia Sur aquifer, located in the lower basin (downstream of Tous), is used as an alternative water source.

Water scarcity, irregular hydrology, and groundwater overdraft result in droughts with significant economic, social, and environmental consequences. This situation is expected to be exacerbated by the impacts of climate and socioeconomic (global) changes and increasing institutional impediments from political disputes among the two main riparian regions, Castilla-La Mancha (upstream; mainly Albacete province) and Valencia (middle and downstream basin). A range of different innovative solutions are considered to face the main water management issues, such as pumping-water right acquisitions during droughts, increasing wastewater reuse, "in lieu" recharge (providing surplus 
surface water to groundwater users, keeping groundwater in storage for later use), water-saving in agriculture through drip irrigation, new water allocation mechanisms, water banks, water pricing, and irrigated crop drought insurances (among others), which makes this case a real lab for analyzing risk management strategies to cope with drought, extreme events, and climate change [43].

The operation of the system, managed by the Jucar River Basin Authority (Confederacion Hidrografica del Jucar, CHJ), is subject to physical, environmental, and legal constraints. The main physical constraints correspond to the reservoir, river, and canal capacities. The environmental constraints are the minimum flows prescribed in certain river reaches and the inflow requirements of the Albufera wetland. The main legal constraint in the Jucar River system is the Alarcon Agreement, signed between the Spanish Ministry of the Environment and the senior users of the Jucar River-mainly farmers-gathered together in the Unidad Sindical de Usuarios del Jucar (USUJ). The agreement divides Alarcon in two zones by a rule curve. If the water level in Alarcon is above the threshold, water can be freely allocated, but if the storage is below certain value, water in the system is reserved exclusively for the USUJ members. In this case, other water users who want to access water from the Jucar River would have to pay a financial compensation to USUJ. The operators also follow additional criteria to decide the releases during the irrigation period (May-September): not causing undesired spills from Tous (the downstream reservoir), not storing more than $450 \mathrm{Mm}^{3}$ in Contreras to avoid stability problems, and not storing more than $72 \mathrm{Mm}^{3}$ in Tous at the end of the summer to avoid flood damage during autumn due to intense rainfall events [42].

The Jucar River basin, as most Mediterranean and south-eastern basins of Spain, is very vulnerable to droughts [11]. The recurrence of these events is also an important factor when considering the management of the system, as a high-frequency appearance of droughts do not allow the system to properly recover water storage to face future water-scarcity events. The latest drought periods (1991-1995; 1997-2000 and 2004-2009) were classified as extreme droughts using the SPI index [14]. During the drought period 2005-2008, surface water available for agriculture decreased by up to $40 \%$ compared to the average. Because of this, drought emergency wells in the lower basin were activated. Despite of these efforts, the drought caused an important economic impact, especially to agriculture activities. The situation is expected to be exacerbated by the impact of climate change [8,44].

A key feature of drought management plans is the indices that define the different drought stages and trigger mitigation measures. Drought indices should capture the state of the water resource system as a whole, allowing the planner to active measures to reduce its impact. Some of the measures for drought management include conjunctive use of surface and groundwater, awareness campaigns to promote domestic water savings, economic tools, control of the supply to agricultural demands from reservoirs, and water reuse [16]. Traditionally, the management of droughts in the Jucar Basin was regulated as an emergency, and the application of Royal Decrees was necessary to mitigate their impacts [12]. From 2007, drought management in the Jucar River system is regulated by a drought management plan $[14,40]$ that establishes a state index to monitor the system and a set of drought management measures triggered by the different drought stages. This index is calculated using different variables distributed in the area of the river basin, including reservoir storages, groundwater levels, streamflow, precipitation, and reservoir inflows. The state index takes values between 0 and 1 , with four system states: normal, pre-alert, alert, and emergency. Then, different drought management measures are applied depending on the system's state index. These measures can be divided into 2 groups, (1) control of water supply for urban and agricultural uses and, (2) increase of water availability by drought emergency wells use and increasing water reuse.

\subsection{System Dynamics for the Jucar River System}

The system dynamics model developed for the Jucar River system represents its current management with a monthly time step, including the state index of the system and the management measures linked to this state. The software Vensim Pro [45] has been used for the creation of the model. The Jucar model was divided into 5 subsystems: 
1. General view of the system: defines the system structure, its three main reservoirs, the connections, intakes, and outflows from the river (Figure 3).

2. Mancha Oriental aquifer: simulates the aquifer using a two-cell embedded multi-reservoir model, in line with the one used by the $\mathrm{CHJ}$ in its water resource management models [40,42].

3. Water demands: defines the different monthly water demands, the distribution of water, and the system deliveries and deficits.

4. Reservoir operation: defines the seasonal operating rules of the system.

5. State index: calculates the state index and defines the management measures to take based on it.

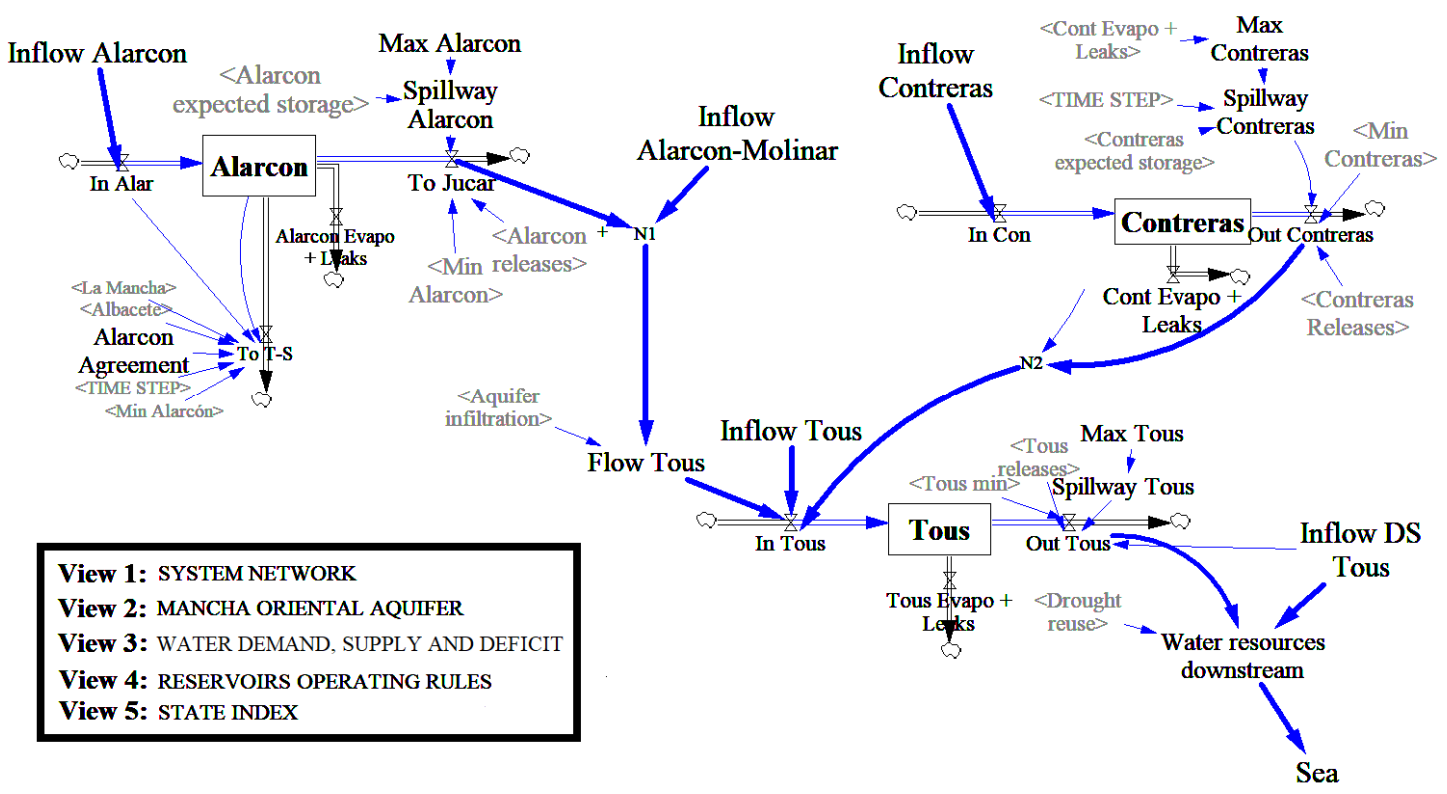

Figure 3. Subsystem for the general view of the system.

The model incorporates monthly water inflows in 5 sub-basins where data from CEDEX [46], the Spanish institution responsible for collecting and supplying data on civil engineering and water, has been obtained and processed. The main view of the model (Figure 3) captures the water flows through the Jucar system, including water infrastructures and stream-aquifer interaction with the Mancha Oriental aquifer. This structure is based on previous models for the area [42], and provides a general framework to visualize the system's network and to allow the integration of other sub-models. The model incorporates a submodel that simulates the current operation of the system (Figure 4), based on historical records and trends of the main variables.

The operating rules of the three reservoirs are defined at the monthly scale, mimicking the operation of the system for the 2003-2013 period, and introducing the constraints that bind the seasonal operation of the Jucar River system. The rules were obtained using fuzzy rule-based systems (FRB), co-developed with the experts from the Operation Office of the Jucar River Basin Authority [42]. A series of workshops and surveys were used to extract the decision-making processes followed in the seasonal operation of the Jucar River system. The implicit operation of the system was encoded into two FRB systems that were validated against historical records on reservoir storages and releases, streamflows, and deliveries to consumptive demands for the 2003-2013 period. The developed FRB were introduced into the SD model through piecewise linear regressions equations (Figure 5). Some flexibility is lost in the process of transforming the FRB rules into linear regressions, as it can be observed in the figure. 


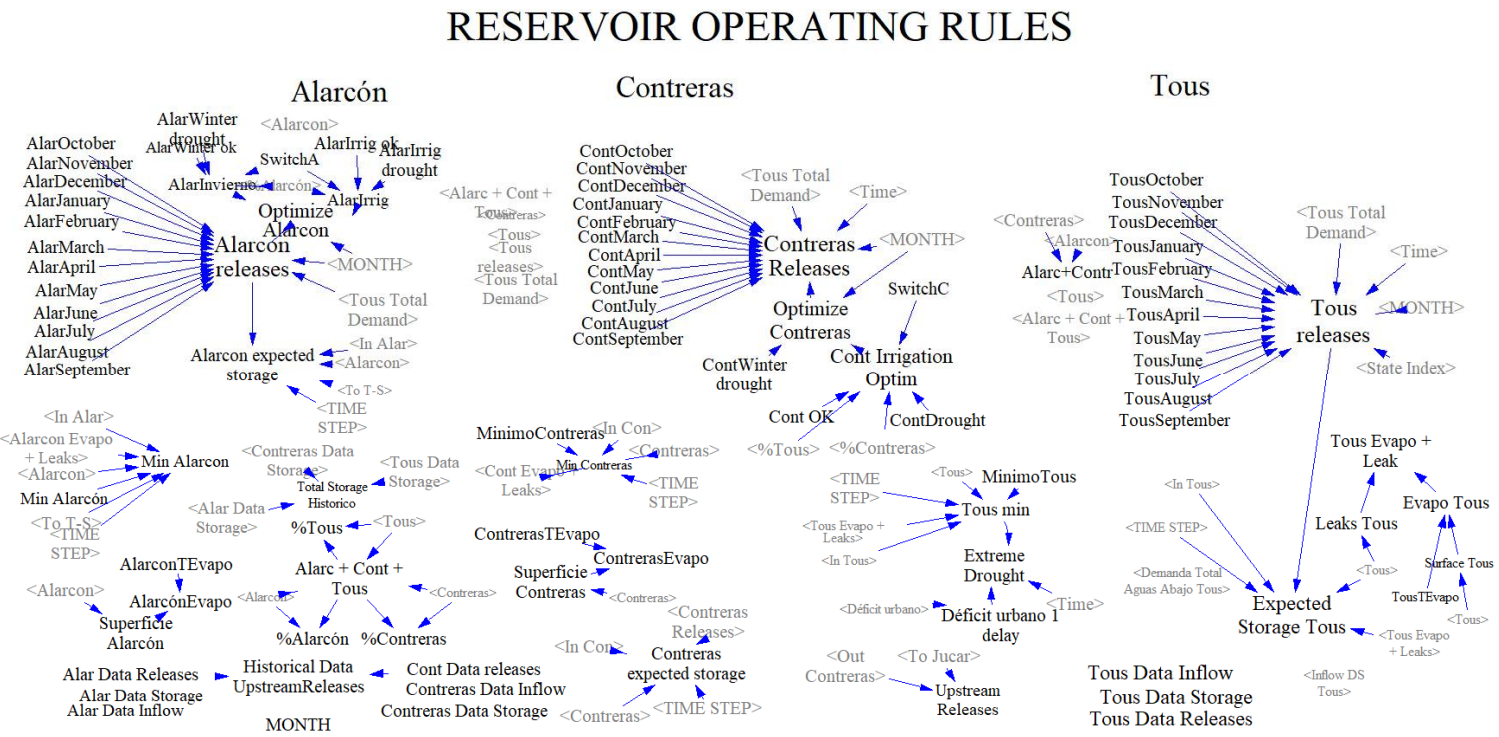

Figure 4. Reservoir operating rules subsystem that incorporates the monthly operating rules for each reservoir, variables, and seasonal parameters that determine final releases.

TOUS JULY OPERATING RULE

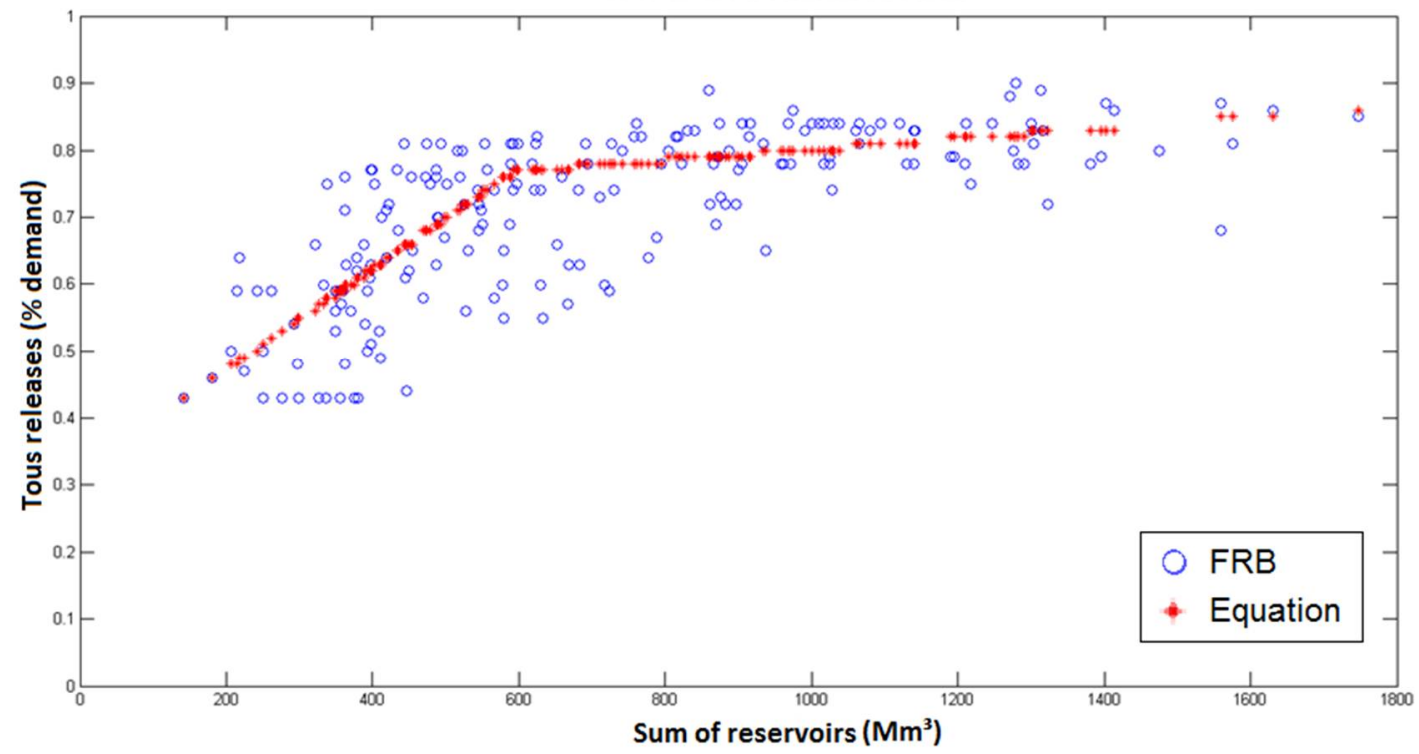

Figure 5. Graphical representation of the simulated operating rule of Tous reservoir in July. Blue dots represent the values of releases using fuzzy logic. Red crosses show values for the piecewise linear regression introduced into the SD model.

To compensate this loss of flexibility, the obtained rules for Alarcon and Contreras reservoirs were adjusted using seasonal factors (depending on whether it was or not irrigation season) and a scarcity factor different for both winter and summer seasons, to account for differences observed in the management of the system that were not correctly captured by the calculated piece-wise linear equations. Releases from Tous were computed as the minimum value between the downstream demand and the releases calculated by the piecewise linear equations. This implies that the system will not release more water from Tous than needed, minimizing unwanted releases to the sea while still capturing the seasonal behavior provided by the operating rules. The Alarcon Agreement was explicitly introduced into the model's formulation.

The water demands considered by the model are divided into urban and agricultural demands and were located and compiled from the public information provided by the $\mathrm{CHJ}$ [47]. Most of them 
are located downstream Tous, although the model also accounts for the demands located in the middle basin, one of them being a groundwater demand that affects the stream-aquifer interaction. The current operating rules of the system prioritizes water allocation to urban uses. Environmental requirements have been considered as a restriction and are captured by the operating rules of the reservoirs.

The model simulates stream-aquifer interaction between the Mancha Oriental aquifer and the Jucar River using a two-cell Embedded Multi-reservoir Model (Figure 6) [48]. Its formulation is based on the analytical solution of the stream-aquifer flow equation applied to linear systems, as well as it analogy with the state equation. Groundwater discharge can be expressed as the theoretical sum of an infinite number of linear reservoirs whose discharge is linearly proportional to the stored volume. In normal conditions, a limited number of linear reservoirs is enough to adequately reproduce groundwater discharge. Although the EMM does not calculate spatially-distributed heads and internal groundwater flows, it can provide an accurate representation of stream-aquifer interactions, even in karstic aquifers [49,50] and it is used in some general DSS services for water resource management [42,51]. Groundwater flow is calculated as the integration of the outflow of 2 linear reservoirs in which the discharge is linearly proportional to the volume stored. The EMM built for the Mancha Oriental aquifer represents exclusively the impacts of the anthropic stresses on stream-aquifer interaction, since the natural discharge was already included in the natural inflow time series of the model [42]. The anthropic-induced net recharge corresponds to the agricultural percolation minus groundwater abstractions. As shown by Macian-Sorribes et al., 2017, the calibrated EMM was able to capture well both the over-year trend and the seasonal variation of the historical values.

CELL 1



Figure 6. Subsystem for the stream aquifer interaction between the Jucar River and the Mancha Oriental aquifer.

The model also implements a state index subsystem. This subsystem checks the state of the system each time-step during the simulation, as does the state index used by the CHJ on a monthly basis. The equations defining the relationship between past and present system states are taken from the Jucar drought management plan [14,52].

The monthly system state index $\left(S_{i}\right)$ has the following expression:

$$
S_{i}=\frac{1}{2}\left[1+\frac{V_{i}-V_{a v}}{V_{\max }-V_{a v}}\right] \text { if } V_{i} \geq V_{a v}
$$




$$
S_{i}=\frac{V_{i}-V_{\min }}{2\left(V_{a v}-V_{\min }\right)} \text { if } V_{i}<V_{a v}
$$

where $V_{i}$ is the value of the variable at the beginning of the month $i$ and $V_{a v}, V_{\max }$ y $V_{\min }$ are the recorded average, maximum and minimum monthly values of the variable since 1982. In the case of the SD model, the subsystem uses historical data of the average, maximum, and minimum value of water storage for each one of the three reservoirs and compares the recorded values to the current state of the system. Although the evaluation of the system state index executed by the water authority for the Jucar River basin takes into account 9 additional variables other than the water storage (including piezometric levels and water inflows), in regulated systems the volume stored in the reservoirs is regarded as a good approximation of the actual status of the whole system [53].

The state index subsystem is able to trigger drought management measures depending on the current state of the system (Figure 7).
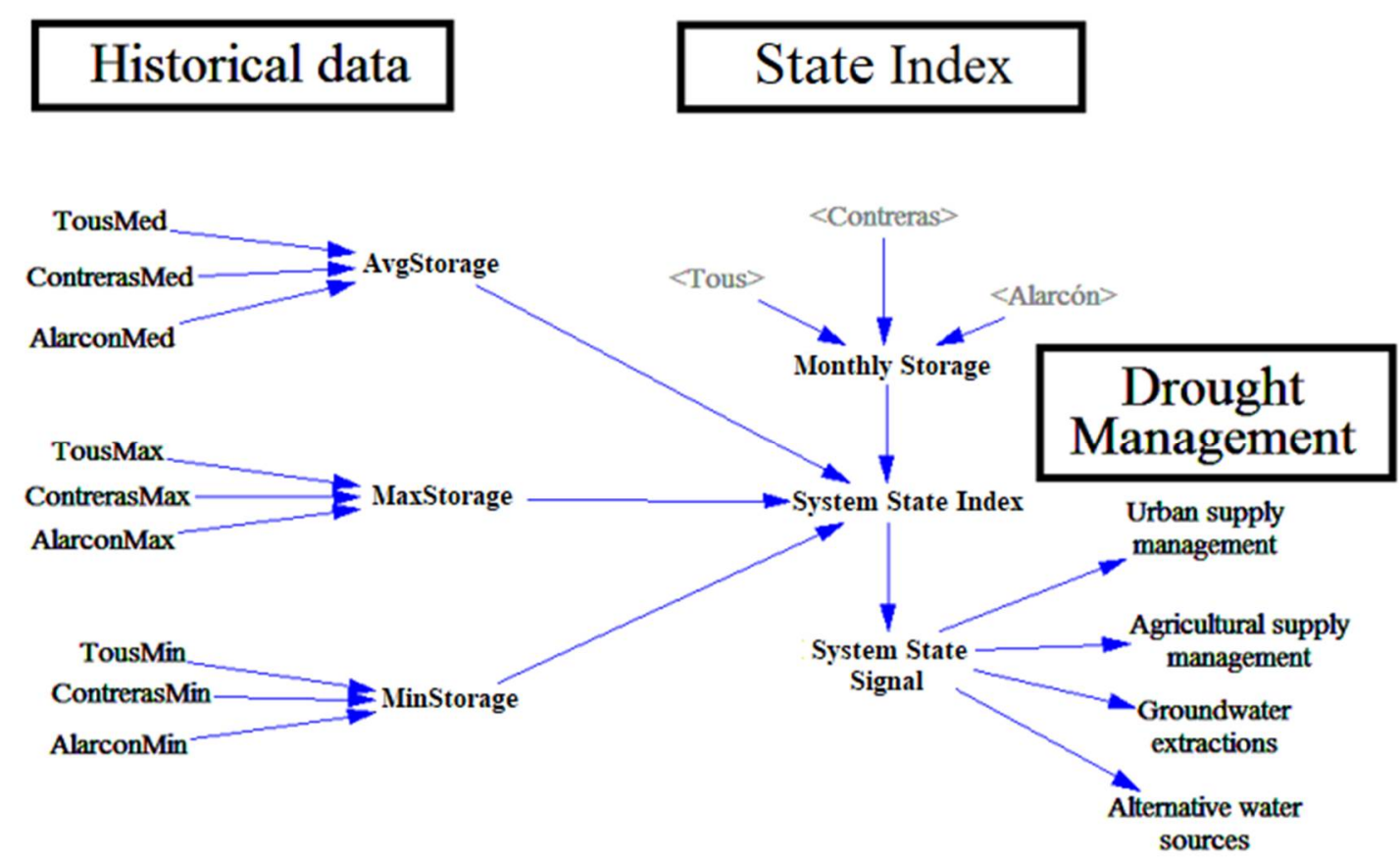

Figure 7. State index subsystem to calculate the system's state comparing with historical data and incorporating drought management strategies.

The system state index takes values that range from 0 to 1 . Each month, the model transforms the system state index (a floating-point number) to the corresponding integer state (normal, pre-alert, alert, and emergency) applying the thresholds defined by the water authority. Drought management strategies defined in this subsystem are introduced as actions into their respective subsystems using shadow variables. The measures implemented consider both supply and demand side solutions. For instance, when triggered, the variable "Agricultural supply management" is linked to the agricultural supply on the "Water demand, supply and deficit" subsystem applying a restriction of $20 \%$ or $40 \%$ on the deliveries to the agricultural demands, depending on the state index. "Urban supply management" restricts the water delivered to the urban demand in alert or worse situations by $5 \%$, reproducing the estimated effect of the water-saving awareness campaigns proposed by the water authority $[14,52]$. "Groundwater extractions" and "Alternative water sources" variables simulate the use of wells and the reuse of wastewater respectively for agricultural supply; the intensity of both actions depends on the monthly state of the system. All the values and management measures represented in the state index subsystem are based on the current drought management plan for the system. 


\section{Results and Discussion}

\subsection{Model Evaluation}

The system dynamics model of the Jucar River system was evaluated using the 2003-2013 period. The comparison between the model's results and historical records showed that the model is able to capture the observed operation (Figure 8). Residual plots for the same variables can be found in Appendix A (Figure A1). Total storage was closely reproduced by the model, as can be observed in the plot and in the R-squared index. The Alarcon and Contreras releases were adequately reproduced on a broader view, due to the resemblance of the intra-annual patterns. However, the model results depart from the historical observations in some years. This is due to the fact that the middle basin is modeled in less detail than the lower one. For instance, hydroelectric production has not been included in the middle basin. In any case, storages in Alarcon and Contreras are adequately reproduced (Figure A2) and the overall in-year dynamics of the system was matched, so these deviations do not have a significant impact on the performance of the model. Tous releases results correctly fit the available data. These releases have a major importance for the model since the majority of the surface water demands are located downstream. As for water supply deficits, the simulated values matched the observed data adequately, including the main peaks associated with the 2005-2008 drought, especially during the years when the drought was more severe. Differences between observed and simulation results can also be explained by the fact that the model assumes a constant annual demand for the whole simulation period while, actually, demands changed due to population change, variation in irrigated areas, and shift from gravity to drip irrigation [47].

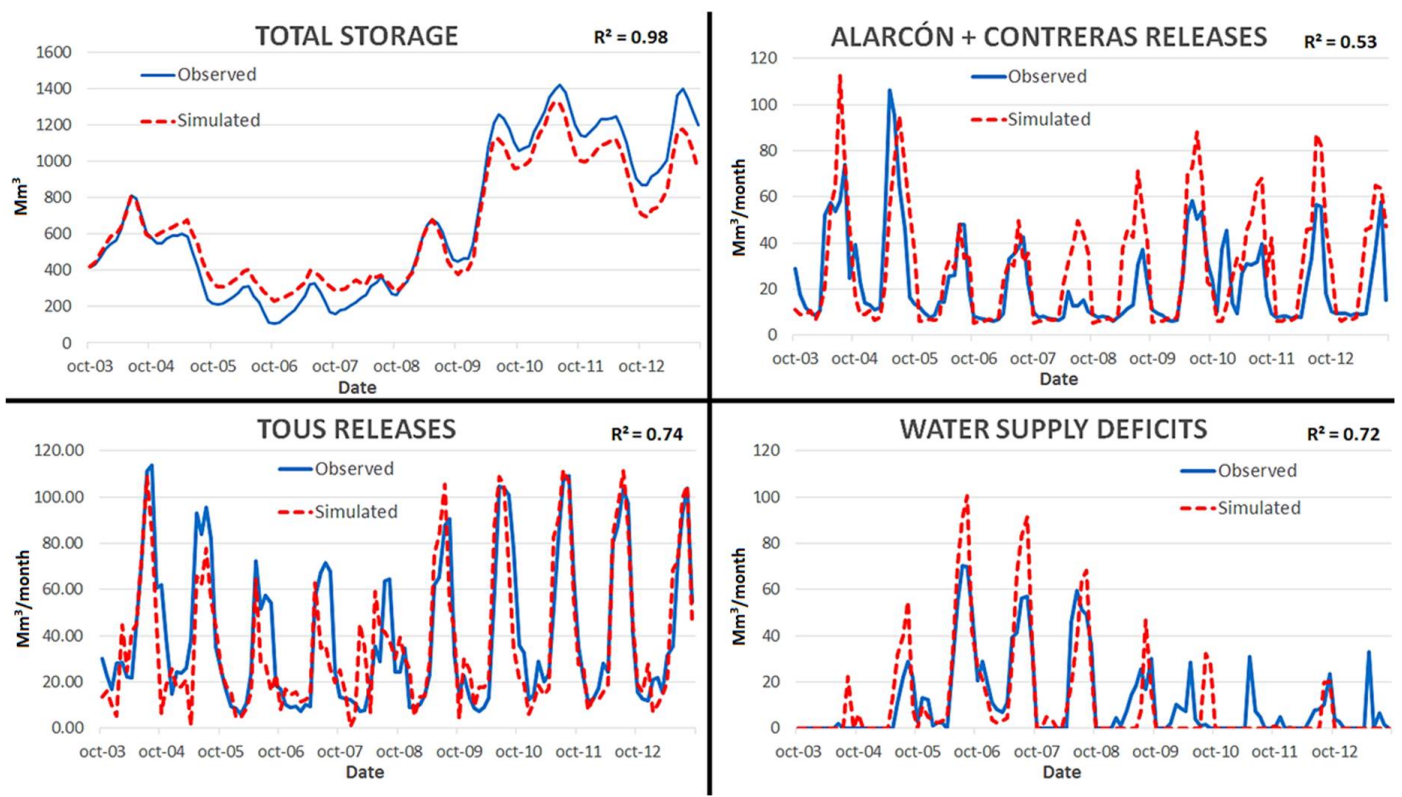

Figure 8. Comparison between observed and simulated values for key variables of the system.

Releases from Alarcon and Contreras are cumbersome to model because of the uncertainties of the middle basin, changes in downstream demands, and varied criteria of releases and management over the simulated period. Although it would be possible to introduce variable demands into the model, there is no available data to represent the variation of all the demands during the simulation period. Furthermore, although the model incorporates monthly operating rules for the reservoirs based on a fuzzy logic representation of the system operation reported by the managers [42], those rules cannot reproduce discretionary changes in the operation of the system during the simulation period. 
Once verified that the developed model matches adequately the historical behavior of the Jucar River system, further simulations were launched to test different management assumptions and scenarios.

\subsection{System State Index and Drought Management Strategies}

The SD model has been applied to study the interaction between the previously indicated drought management strategies and other variables of the system. A comparison between simulations with and without the drought management strategies introduced into the management in 2007 was performed. Results obtained when applying the drought management measures show improvements for the state index of the system and for the system's total water storage (Figure 9).


Figure 9. (a) State index and (b) total storage with and without drought management strategies.

The system state index benefits from applying the drought management strategies defined in the state index subsystem. Thanks to them, the system state does not drop into an emergency state during the 2005-2008 drought. It also recovers earlier from the alert state during that drought, and it enters the prealert stage months before than the scenario with no drought management measures. 
After the system enters a normal state, it is worth pointing out that the state index is higher for the drought managed model, even when the drought is over (from 2010 onwards). According to the model, water storage in reservoirs is increased significantly when drought management measures are applied. The difference is up to almost $100 \mathrm{Mm}^{3}$ during October 2008. This is the result of the management strategies taken in anticipation thanks to the state index and the four threshold levels defined. The anticipated management also allows to reduce the system vulnerability by $62 \%$ in comparison with the scenario without drought management and considering vulnerability as the ratio between total water supply deficit and the number of failures to meet the demands during the whole period. A reduction in vulnerability means that the average water shortage is lower, although the frequency of these shortages may increase. These drought management measures entail the use of drought emergency wells for water abstraction within a maximum of $98 \mathrm{Mm}^{3} /$ year (Figure 10) following the plan defined by the water authority $[14,52]$.

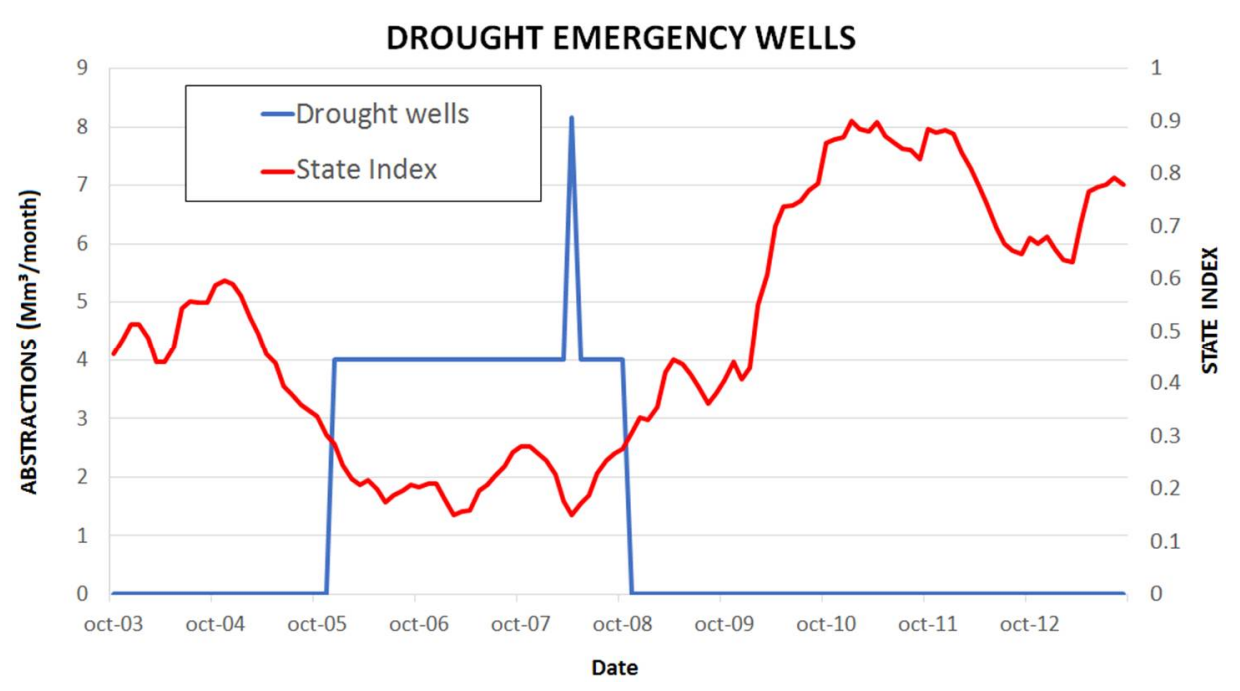

Figure 10. Water abstraction from emergency wells during drought compared to the system state index.

Water pumping from drought emergency wells located in the lower basin compensates the reduced surface water supply and alleviate the drought impact on agriculture. These groundwater abstractions are activated when the system falls into the alert state, and water abstraction scale up above $8 \mathrm{Mm}^{3} /$ month if the emergency state is reached (Figure 10).

\subsection{Economic Impact of Droughts}

Results show that the total reservoir storage of the basin improves when drought management measures are applied. It is to expect that the gained storage will benefit the early recovery of the system allowing for more regular deliveries to agricultural demands. Indeed, it is possible to calculate the economic losses associated with the mismanagement of droughts for the 2003-2009 period (Figure 11).

Economic losses were calculated by economically characterizing the monthly demands of the system defined as targets [47] using demand curves or functions obtained by Positive Mathematical Programming (PMP) [54] for the different agricultural demands [55]. Benefits were obtained as the integration of the demand function between zero and the level of supply. It can be observed (Figure 11) that economic losses concentrate on the drought period (2005-2008), particularly when the system state index stays in alert for several months (2006-2008). During the irrigation season in drought periods is when economic losses rise due to water scarcity. The fact that, as defined by the drought management strategies subsystem, in alert and emergency states the water supply for agriculture is reduced by up to $40 \%$ its original demand could be thought of as detrimental for agricultural interests. However, according to the simulations, the water saved helps a faster recovery of the system, guarantees urban water supply, and reduces the long-term impact of droughts. In the model, the economic impact of the 
2005-2008 drought was reduced from 89 M€ to 29 M€ thanks to the drought management strategies implemented. Due to conjunctive use of superficial and groundwater, agricultural activities suffer lower impact even considering the significant restrictions they suffer during the alert and emergency states. When the amount of available water is scarce, using groundwater to supply crops under deficit irrigation guarantees the survival of the plantations and minimizes economic losses.

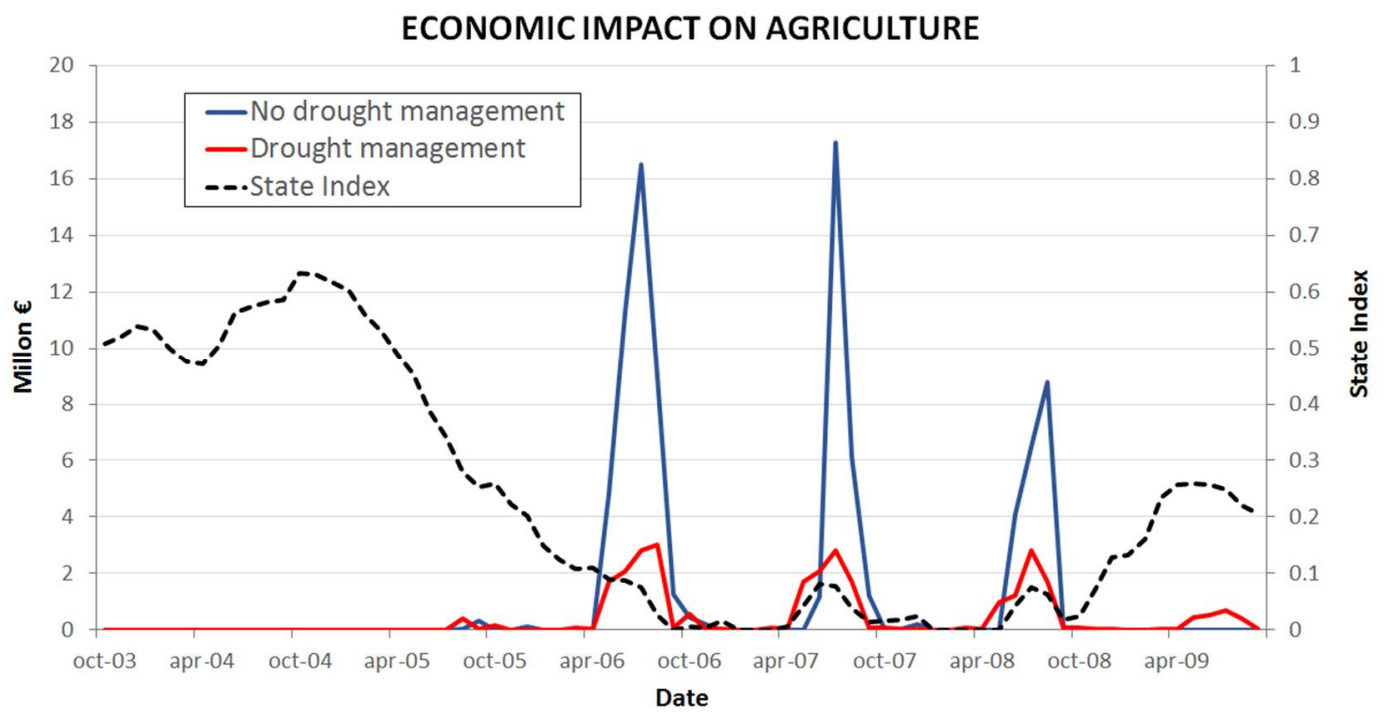

Figure 11. Estimation of economic losses for agriculture compared to the system state index during the 2000's drought.

\section{Conclusions}

This paper presents a system dynamics DSS for drought management of the Jucar River system, taking into account the combination of a state index and several drought management strategies. The resulting DSS showed the potential of system dynamics for simulating the management of multi-reservoir systems, integrating monthly-defined operating rules for the reservoirs, stream-aquifer interaction, conflicting water demands, and drought management strategies. The model adequately reproduces the operation of the system and is able to produce accurate quantitative results, as shown by the comparison with the historical records.

The DSS takes advantage of the holistic concept that drives the methodology and incorporates components from different disciplines (hydrology, economics, social sciences, laws, etc.) into its modular structure. The state index subsystem is an example of how it is possible to integrate policies and management strategies into a water resource model using a system dynamics approach. Likewise, water policy or legislation has been incorporated into the model-e.g., the Alarcon agreement.

The DSS opens up the possibility of analyzing different drought management strategies and assessing the interactions, feedbacks, and impacts within and between multiple sectors and variables.

Results showed that drought management strategies have a net positive effect in the Jucar River system from both the economic (agriculture) and the water management perspective. The defined measures lowered agricultural losses for the 2005-2008 drought period and increased the amount of stored water during drought allowing the faster recovery of the system. Although the model provides quantitative results similar to the historical data available, the main goal of a system dynamics model is neither to forecast nor to optimize, but studying patterns, trends, and interactions between different variables of the model [24]. Modeling and dynamically simulating the change in water resources over time provides a scientifically defensible basis for proactive management strategies, enhancing our prospects to maximize the adaptive capacity of the system as a whole [29]. 
Moreover, the same methodology used to study drought management strategies can be applied to study the impact of different realities and inputs into the system. The DSS model developed for the Jucar River system uses a quantitative approach for its simulation. Consequently, it requires numeric data and well-tuned equations to capture the behavior of the system in detail. Qualitative variables and inputs can also be implemented in this kind of model. Qualitative modeling often introduces "soft" variables to study the general patterns of behavior of the model, rather than precise numbers [56]. In this case, qualitative modeling can be restricted to new subsystems for the testing of different non-easily quantifiable hypothesis.

The model herein presented was successfully developed for the Jucar case study and it could be replicated in any basin or system where enough information and data are available. The development of quantitative system dynamics models requires the use of a large volume of data coming from different fields (from hydrological to economic and reservoir data) as well as a deep understanding of the system structure and behavior. Very often, the most complex issue of this type of model is the development of the monthly operating rules for the reservoirs. In this case, the final rules were inferred using fuzzy logic, but additional tests showed that it is possible to simulate the operation of the system using other approaches and calibrating the rules with the historical records for the releases and water storage of the reservoirs. Although the model is able to reproduce the stream aquifer interaction between the Jucar River and the Mancha Oriental aquifer, it simulates neither groundwater heads nor aquifer storage. Groundwater head specifically is a determinant factor for the Mancha Oriental aquifer, as it has suffered continuous drops in groundwater levels due to intense pumping since the early 1970s. To assess the effect of drought policies on groundwater levels, it would be necessary to apply a detailed groundwater model, such as finite-difference model, coupling it with the system dynamics model either through scripting, wrapping, or spreadsheet coupling [57].

The model developed using system dynamics for the Jucar River system has the potential to grow and increase its scope by integrating new dynamics that can modify the behavior of the whole system. Future lines of work include linking the agricultural demand subsystem and a land-use subsystem, which would allow for introducing changes in agricultural land use based on economic benefit from previous years and on changes in land-use policies. System dynamics provides an excellent framework to study trade-offs that land use changes can introduce in specific sectors and communities [58]. Furthermore, it is already possible to activate population growths or losses over time to study how changes in urban demand can affect the system. These functionalities are required to test the effect of different climate change narratives within the next decades, which is also a future line of research to explore.

Author Contributions: Conceptualization, A.R.-M. and M.P.-V.; methodology, H.M.-S. and M.P.-V.; software, A.R.-M. and H.M.-S.; validation, A.R.-M. and H.M.-S.; formal analysis, A.R.-M. and H.M.-S.; investigation, A.R.-M., H.M.-S. and M.P.-V.; resources, A.G.-P. and M.P.-V.; data curation, A.R.-M. and H.M.-S.; writing-original draft preparation, A.R.-M.; writing—review and editing, A.G.-P., H.M.-S. and M.P.-V.; visualization, A.G.-P., A.R.-M., H.M.-S. and M.P.-V.; supervision, A.G.-P. and M.P.-V.; project administration, A.G.-P. and M.P.-V.; funding acquisition, A.G.-P. and M.P.-V. All authors have read and agreed to the published version of the manuscript.

Funding: The data used in this study was obtained from the references included. We acknowledge the European Research Area for Climate Services consortium (ER4CS) and the Agencia Estatal de Investigación for their financial support to this research under the INNOVA project (Grant Agreement: 690462; PCIN-2017-066). This study has also been partially funded by the ADAPTAMED project (RTI2018-101483-B-I00) from the Ministerio de Ciencia, Innovación y Universidades (MICIU) of Spain.

Conflicts of Interest: The authors declare no conflict of interest. 


\section{Appendix A}
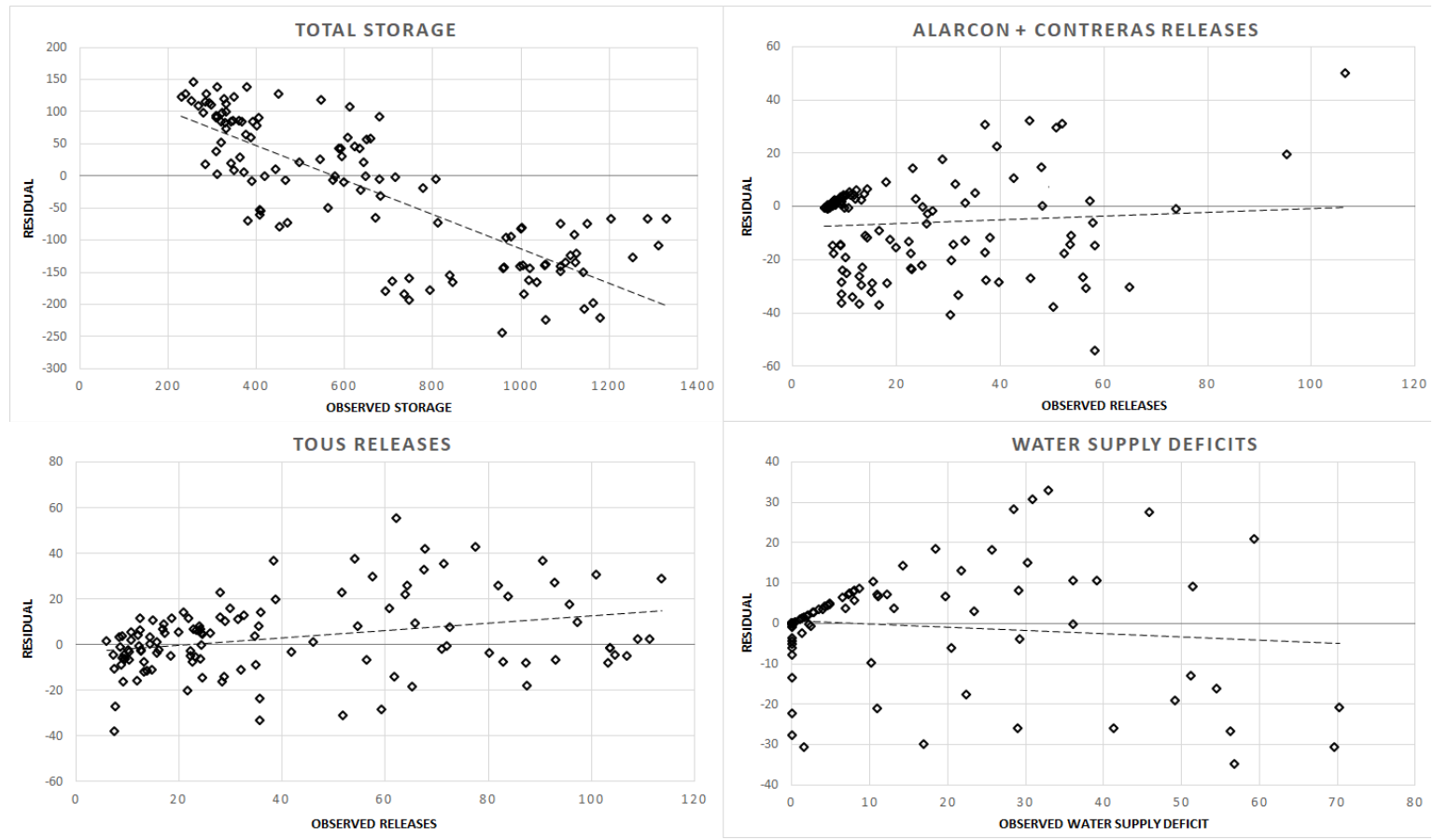

Figure A1. Residual plots of the variables presented in Figure 8.

The residuals for the variables of Alarcon \& Contreras releases, Tous releases, and water supply deficit show a lack of general pattern and are distributed pretty symmetrically around the 0 line. Total storage, however, shows a pattern that was already observed in Figure 8: the model tends to store more water at the beginning of the decade and during the drought period, and it storages less water towards the late period. Several reasons have been given to explain this pattern. As most water resource management models, stationary conditions have been assumed for water demand and reservoir operation during the whole period. However, in reality, water demand and the operation of the reservoirs was changing during the 10-year period. There is not available data to correctly represent the variation of all the water demands, but we know that the demand at the beginning of the decade was greater than during the last years, due to changes in regulation and the improvement of control. We have assumed an average water demand based on the available data. This may explain in part why the model has more water than the observed at the beginning (in reality, the water demand was greater than the introduced) and less at the end (the water demand introduced is greater in the model). The same trend can be observed in Figure A2. Regarding the impact of the operating rules in the results, the rules are based on interviews and analysis performed in collaboration with the decision-makers [42] and are, in some regard, influenced by the knowledge gained during the decade simulated in our model. In reality the logic behind the operation of the reservoirs was evolving and changing during the whole period. 

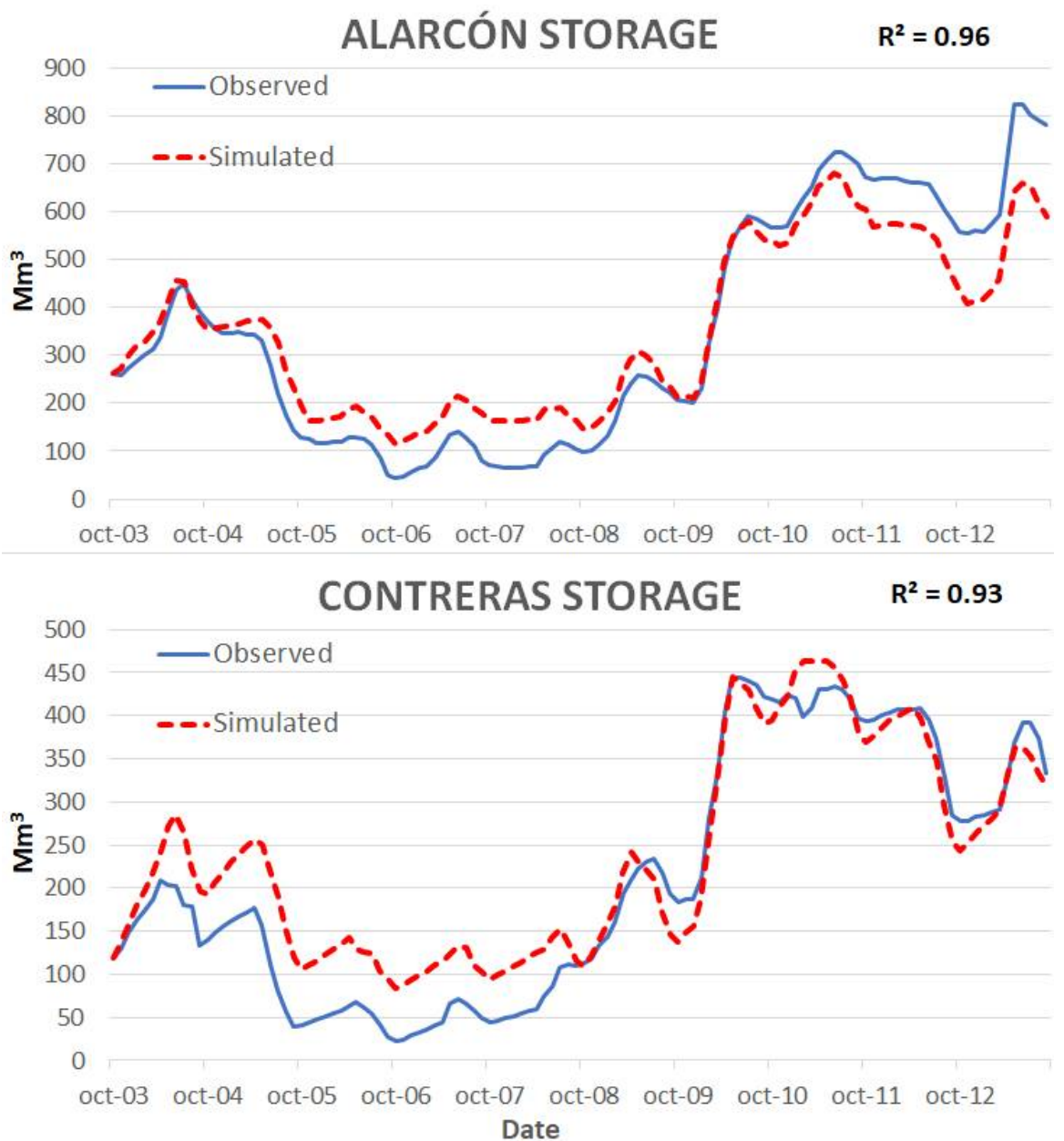

Figure A2. Observed vs simulated storage in Alarcon and Contreras reservoirs.

\section{References}

1. Wilhite, D.A.; Buchanan-Smith, M. Drought as Hazard: Understanding the Natural and Social Context. In Drought and Water Crisis. Science Technology and Management Issues; CRC Press Taylor and Francis: Boca Raton, FL, USA, 2005; pp. 3-27. ISBN 9780367393205.

2. Mishra, A.K.; Singh, V.P. A review of drought concepts. J. Hydrol. 2010, 391, 202-216. [CrossRef]

3. Momblanch, A.; Paredes-Arquiola, J.; Munné, A.; Manzano, A.; Arnau, J.; Andreu, J. Managing water quality under drought conditions in the Llobregat River Basin. Sci. Total Environ. 2015, 503-504, 300-318. [CrossRef] [PubMed]

4. Agrawala, S.; Barlow, M.; Heidi, C.; Lyon, B.; IRI International Research Institute for Climate and Society. The Drought and Humanitarian Crisis in Central and Southwest Asia: A Climate Perspective; IRI Spec. Rep. NO. 01-11; IRI: Palisades, NY, USA, 2001; Volume 20.

5. Van Loon, A.F.; Van Lanen, H.A.J. Making the distinction between water scarcity and drought using an observation-modeling framework. Water Resour. Res. 2013, 49, 1483-1502. [CrossRef]

6. Mishra, A.K.; Singh, V.P. Drought modeling - A review. J. Hydrol. 2011, 403, 157-175. [CrossRef]

7. Wilhite, D.A.; Sivakumar, M.V.K.; Pulwarty, R. Managing drought risk in a changing climate: The role of national drought policy. Weather Clim. Extrem. 2014, 3, 4-13. [CrossRef]

8. Marcos-Garcia, P.; Lopez-Nicolas, A.; Pulido-Velazquez, M. Combined use of relative drought indices to analyze climate change impact on meteorological and hydrological droughts in a Mediterranean basin. $J$. Hydrol. 2017, 554, 292-305. [CrossRef]

9. European Commission. Addressing the challenge of water scarcity and droughts in the European Union. J. Chem. Inf. Model. 2013, 53, 1689-1699. 
10. Strosser, P.; Dworak, T.; Garzón Delvaux, P.A.; Berglund, M.; Schmidt, G.; Mysiak, J.; Kossida, M.; Iacovides, I.; Ashton, V. Gap Analysis of the Water Scarcity and Droughts Policy in the EU. SWD 380 Final; European Commission: Brussels, Belgium, 2012.

11. Estrela, T.; Vargas, E. Drought Management Plans in the European Union. The Case of Spain. Water Resour. Manag. 2012, 26, 1537-1553. [CrossRef]

12. Pedro-Monzonís, M.; Solera, A.; Ferrer, J.; Estrela, T.; Paredes-Arquiola, J. A review of water scarcity and drought indexes in water resources planning and management. J. Hydrol. 2015, 527, 482-493. [CrossRef]

13. Zaniolo, M.; Giuliani, M.; Castelletti, A.F.; Pulido-Velazquez, M. Automatic design of basin-specific drought indexes for highly regulated water systems. Hydrol. Earth Syst. Sci. 2018, 22, 2409-2424. [CrossRef]

14. CHJ (Confederación Hidrográfica del Júcar). Plan Especial de Alerta y Eventual Sequía en la Confederación Hidrográfica del Júcar; Confederación Hidrográfica del Júcar: Valencia, Spain, 2007; p. 185.

15. Carmona, M.; Máñez Costa, M.; Andreu, J.; Pulido-Velazquez, M.; Haro-Monteagudo, D.; Lopez-Nicolas, A.; Cremades, R. Assessing the effectiveness of Multi-Sector Partnerships to manage droughts: The case of the Jucar river basin. Earth's Futur. 2017, 5, 750-770. [CrossRef]

16. Iglesias, A.; Cancelliere, A.; Wilhite, D.A.; Garrote, L.; Cubillo, F. Coping with Drought Risk in Agriculture and Water Supply Systems. Drought Management and Policy Development in the Mediterranean; Iglesias, A., Garrote, L., Cancelliere, A., Cubillo, F., Wilhite, D.A., Eds.; Springer Netherlands: Dordrecht, The Netherland, 2009; ISBN 978-1-4020-9044-8.

17. Pallottino, S.; Sechi, G.M.; Zuddas, P. A DSS for water resources management under uncertainty by scenario analysis. Environ. Model. Softw. 2005, 20, 1031-1042. [CrossRef]

18. Sechi, G.M.; Sulis, A. Drought mitigation using operative indicators in complex water systems. Phys. Chem. Earth 2010, 35, 195-203. [CrossRef]

19. Svoboda, M.D.; Fuchs, B.A.; Poulsen, C.C.; Nothwehr, J.R. The drought risk atlas: Enhancing decision support for drought risk management in the United States. J. Hydrol. 2015, 526, 274-286. [CrossRef]

20. Buttafuoco, G.; Caloiero, T.; Ricca, N.; Guagliardi, I. Assessment of drought and its uncertainty in a southern Italy area (Calabria region). Meas. J. Int. Meas. Confed. 2018, 113, 205-210. [CrossRef]

21. Iglesias, A.; Garrote, L. Adaptation strategies for agricultural water management under climate change in Europe. Agric. Water Manag. 2015, 155, 113-124. [CrossRef]

22. Lewandowski, J.; Meinikmann, K.; Krause, S. Groundwater-surface water interactions: Recent advances and interdisciplinary challenges. Water (Switzerland) 2020, 12, 296. [CrossRef]

23. Forrester, J.W. Industrial Dynamics-After the First Decade. Manag. Sci. 1968, 14, 398-415. [CrossRef]

24. Sušnik, J.; Molina, J.L.; Vamvakeridou-Lyroudia, L.S.; Savić, D.A.; Kapelan, Z. Comparative Analysis of System Dynamics and Object-Oriented Bayesian Networks Modelling for Water Systems Management. Water Resour. Manag. 2013, 27, 819-841. [CrossRef]

25. Mirchi, A.; Madani, K.; Watkins, D.; Ahmad, S. Synthesis of System Dynamics Tools for Holistic Conceptualization of Water Resources Problems. Water Resour. Manag. 2012, 26, 2421-2442. [CrossRef]

26. Simonovic, S.P. World water dynamics: Global modeling of water resources. J. Environ. Manag. 2002, 66, 249-267. [CrossRef]

27. Saysel, A.K.; Barlas, Y.; Yenigün, O. Environmental sustainability in an agricultural development project: A system dynamics approach. J. Environ. Manag. 2002, 64, 247-260. [CrossRef]

28. Sterman, J.D. Business Dynamics: Systems Thinking and Modeling for a Complex World; McGraw-Hill Education: New York, NY, USA, 2000; ISBN 0072311355.

29. Winz, I.; Brierley, G.; Trowsdale, S. The use of system dynamics simulation in water resources management. Water Resour. Manag. 2009, 23, 1301-1323. [CrossRef]

30. Nikolic, V.V.; Simonovic, S.P. Multi-method Modeling Framework for Support of Integrated Water Resources Management. Environ. Process. 2015, 2, 461-483. [CrossRef]

31. Madani, K.; Mariño, M.A. System dynamics analysis for managing Iran's Zayandeh-rud river basin. Water Resour. Manag. 2009, 23, 2163-2187. [CrossRef]

32. Gleick, P.H. A Look at Twenty-first Century Water Resources Development. Water Int. 2000, 25, 127-138. [CrossRef]

33. Qaiser, K.; Ahmad, S.; Johnson, W.; Batista, J. Evaluating the impact of water conservation on fate of outdoor water use: A study in an arid region. J. Environ. Manag. 2011, 92, 2061-2068. [CrossRef] 
34. Sušnik, J.; Vamvakeridou-Lyroudia, L.S.; Savić, D.A.; Kapelan, Z. Integrated System Dynamics Modelling for water scarcity assessment: Case study of the Kairouan region. Sci. Total Environ. 2012, 440, 290-306. [CrossRef]

35. Sehlke, G.; Jacobson, J. System dynamics modeling of transboundary systems: The river basin model. Ground Water 2005, 43, 722-730. [CrossRef]

36. Ahmad, S.; Simonovic, S.P. Modeling Dynamic Processes in Space and Time-A Spatial System Dynamics Approach. In Proceedings of the Bridging the Gap-World Water and Environmental Resources Congress 2001, Orlando, FL, USA, 20-24 May, 2001; American Society of Civil Engineers: Reston, VA, USA, 2001; Volume 48, pp. 1-20.

37. Li, L.; Simonovic, S.P. System dynamics model for predicting floods from snowmelt in north American prairie watersheds. Hydrol. Process. 2002, 16, 2645-2666. [CrossRef]

38. Ahmad, S.; Prashar, D. Evaluating Municipal Water Conservation Policies Using a Dynamic Simulation Model. Water Resour. Manag. 2010, 24, 3371-3395. [CrossRef]

39. De Araujo, W.C.; Oliveira Esquerre, K.P.; Sahin, O. Building a system dynamics model to support water management: A case study of the semiarid region in the Brazilian northeast. Water (Switzerland) 2019, 11, 2513.

40. CHJ (Confederación Hidrográfica del Júcar). Plan Hidrológico de la Demarcación Hidrográfica del Júcar Ciclo 2015-2021; Confederación Hidrográfica del Júcar: Valencia, Spain, 2015; pp. 286-392.

41. Apperl, B.; Pulido-Velazquez, M.; Andreu, J.; Karjalainen, T.P. Contribution of the multi-attribute value theory to conflict resolution in groundwater management - Application to the Mancha Oriental groundwater system, Spain. Hydrol. Earth Syst. Sci. 2015, 19, 1325-1337. [CrossRef]

42. Macian-Sorribes, H.; Pulido-Velazquez, M. Integrating historical operating decisions and expert criteria into a DSS for the management of a multireservoir system. J. Water Resour. Plan. Manag. 2017, 143, 1-12. [CrossRef]

43. CHJ. Plan Hidrológico de la Demarcación Hidrográfica del Júcar. Memoria-Anejo 10. Programa de Medidas. Ciclo 2015-2021; Confederación Hidrográfica del Júcar: Valencia, Spain, 2015; pp. 26-37.

44. Escriva-Bou, A.; Pulido-Velazquez, M.; Pulido-Velazquez, D. Economic Value of Climate Change Adaptation Strategies for Water Management in Spain's Jucar Basin. J. Water Resour. Plan. Manag. 2017, 143, 04017005. [CrossRef]

45. Ventana Systems. Vensim User's Guide; Ventana Systems, Inc., Ed.; Ventana Systems: Harvard, MA, USA, 2019.

46. CEDEX (Centro de Estudios y Experimentación de Obras Públicas). Anuario de Aforos by the Minister of Agriculture Food and Environment; Centro de Estudios y Experimentación de Obras Públicas: Madrid, Spain, 2016.

47. CHJ (Confederación Hidrográfica del Júcar). Plan Hidrológico de la Demarcación Hidrográfica del Júcar. Memoria-Anejo 3. Usos y Demandas. Ciclo 2015-2021; Confederación Hidrográfica del Júcar: Valencia, Spain, 2015; pp. 144-161.

48. Pulido-Velazquez, M.A.; Sahuquillo-Herraiz, A.; Camilo Ochoa-Rivera, J.; Pulido-Velazquez, D. Modeling of stream-aquifer interaction: The embedded multireservoir model. J. Hydrol. 2005, 313, 166-181. [CrossRef]

49. Sahuquillo, A. An eigenvalue numerical technique for solving unsteady linear groundwater models continuously in time. Water Resour. Res. 1983, 19, 87-93. [CrossRef]

50. Estrela, T.; Sahuquillo, A. Modeling the Response of a Karstic Spring at Arteta Aquifer in Spain. Ground Water 1997, 35, 18-24. [CrossRef]

51. Andreu, J.; Capilla, J.; Sanchis, E. AQUATOOL_Generalized_Decision-support_System_for_Water-resources. J. Hydrol. 1996, 177, 269-291. [CrossRef]

52. CHJ (Confederación Hidrográfica del Júcar, O.A.). Plan Especial de Sequía Demarcación Hidrográfica del Júcar; Confederación Hidrográfica del Júcar: Valencia, Spain, 2018; pp. 151-166.

53. Haro-Monteagudo, D.; Solera, A.; Andreu, J. Drought early warning based on optimal risk forecasts in regulated river systems: Application to the Jucar River Basin (Spain). J. Hydrol. 2017, 544, 36-45. [CrossRef]

54. Howitt, R.E. Positive Mathematical Programming. Am. J. Agric. Econ. 1995, 77, 329-342. [CrossRef]

55. Pulido-Velazquez, M.; Perez-Martin, M.A.; Solera, A.; Collazos, G.; Deidda, D.; Alvarez-Mendiola, E.; Benitez, A.; Andreu, J. Desarrollo y aplicacion de metodologias y herramientas en la cuenca piloto del rio Jucar para los analisis economicos requeridos en la Directiva Marco Europea del Agua (in Spanish). In Final Report of EPTISA S.A. and UPV Research Project; Research Institute of Water and Environmental Engineering (IIAMA), Universitat Politècnica de València: Valencia, Spain, 2006; pp. 10-21. 
56. Coyle, G.; Road, C.; Sn, S. Qualitative Modelling in System Dynamics or What are the Wise Limits of Quantification? In Proceedings of the 17th International conference of the system dynamics society, Wellington, New Zealand, 20-23 July 1999; pp. 1-22.

57. Malard, J.J.; Inam, A.; Hassanzadeh, E.; Adamowski, J.; Tuy, H.A.; Melgar-Quiñonez, H. Development of a software tool for rapid, reproducible, and stakeholder-friendly dynamic coupling of system dynamics and physically-based models. Environ. Model. Softw. 2017, 96, 410-420. [CrossRef]

58. Vidal-Legaz, B.; Martínez-Fernández, J.; Picón, A.S.; Pugnaire, F.I. Trade-offs between maintenance of ecosystem services and socio-economic development in rural mountainous communities in southern Spain: A dynamic simulation approach. J. Environ. Manag. 2013, 131, 280-297. [CrossRef]

(C) 2020 by the authors. Licensee MDPI, Basel, Switzerland. This article is an open access article distributed under the terms and conditions of the Creative Commons Attribution (CC BY) license (http://creativecommons.org/licenses/by/4.0/). 